\section{Molecular characterization and genetic diversity of Staphylococcus aureus isolates of dairy production farms in Rio de Janeiro, Brazil}

\author{
Caracterização molecular e diversidade genética de \\ Staphylococcus aureus isolados de fazendas leiteiras no \\ Rio de Janeiro, Brasil
}

Bianca da Silva Soares', Cássia Couto da Motta², Nicolle Lima Barbieri, Dayanne Araújo de Melo ${ }^{4}$, Marisol Alvim Gomez ${ }^{5}$, Tatiani Abreu de Alencar ${ }^{4}$, Irene da Silva Coelho ${ }^{6}$, Shana de Mattos de Oliveira Coelho Catherine Mary Logue ${ }^{8}$, Miliane Moreira Soares de Souza ${ }^{9}$

'Biologist, DSc. Programa de Pós-Graduação em Ciências Veterinárias (PPGCV), Departamento de Microbiologia e Imunologia (DMI), Instituto de Veterinária (IV), Universidade Federal Rural do Rio de Janeiro (UFRRJ), Campus Seropédica, RJ, Brazil

2 Veterinarian, DSc., PPGCV, DMI, IV, UFRRJ, Campus Seropédica, RJ, Brazil

${ }^{3}$ Pharmacist, Dsc., Department of Population Health, College of Veterinary Medicine, University of Georgia, Athens, GA, United States of America

${ }^{4}$ Veterinarian, DSc., Programa De Pós-Graduação Em Ciência, Tecnologia E Inovação Em Agropecuária (PPGCTIA), Universidade Federal Rural do Rio de Janeiro (UFRRJ), Campus Seropédica, RJ, Brazil

${ }^{5}$ Veterinarian, MSc., PPGCV, DMI, IV, UFRRJ, Campus Seropédica, RJ, Brazil

${ }^{6}$ Agronomist, DSc., DMI, IV, UFRRJ, Campus Seropédica, RJ, Brazil

${ }^{7}$ Biologist, DSc., DMI, IV, UFRRJ, Campus Seropédica, RJ, Brazil

${ }^{8}$ Food Science and Technology, DSc., Department of Population Health, College of Veterinary Medicine, University of Georgia, Athens, GA, United States of America

${ }^{9}$ Veterinarian, DSc., DMI, IV, UFRRJ, Campus Seropédica, RJ, Brazil

\begin{abstract}
Staphylococcus aureus is an important pathogen involved in subclinical bovine mastitis, causing high economic losses for the dairy industry. The successful persistence of this pathogen in the host occurs due to a series of factors associated with colonization ability and the acquisition of virulence factors. This bacterial species carries genetic heterogeneity, and genetically diverse strains characterize the population. Analysis of the genetic variation is an important tool for epidemiological studies. For this study, S. aureus strains were randomly selected by molecular profiling. All strains were originated from the milk of cows of subclinical mastitis on farms in the State of Rio de Janeiro. Strains of S. aureus were profiled using virulence gene analysis profiles, agr and spa typing, Pulsed Field Gel Electrophoresis (PFGE), and Multilocus Sequence Typing (MLST). 47\% (8/17) of the tested strains were positive strains for icaA gene; $82.3 \%$ (14/17) for icaD gene; $41 \%$ ( $7 / 17$ ) for $f b n A$ gene; $47 \%$ (8/17) positive for $f b n B$ gene; $94 \%$ (16/17) for the $b l$ g gene and 70.5\% (12/17) for $h / B$ gene. These virulence results generated 11 different profiles. Most strains ( $58.8 \%$ - 10/17) were classified as type-II by agr system. spa typing identified seven different spa types. PFGE analysis found extensive genetic heterogeneity and no clones were observed. MLST analysis generated five different types of ST/CC. Considering the results observed at the present study, a high genetic variety of $S$. aureus strains associated of the presence of different virulence factors justified the absence of clonal strains at the properties evaluated. Besides, that, the definition of S. aureus clonal strain as well dynamic population in not fully understood since there are a limited number of studies in S. aureus associated with bovine mastitis.
\end{abstract}

Keywords: Bovine mastitis, virulence profile, molecular typing.

\section{Resumo}

Staphylococcus aureus éum importantepatógeno envolvido namastitesubclínica bovina, causando altas perdas econômicas para a indústria de laticínios. A persistência bem-sucedida desse patógeno no hospedeiro ocorre devido auma série de fatores associados à capacidade de colonização e aquisição de fatores de virulência. Esta espécie bacteriana possui heterogeneidade genética e a população é caracterizada por cepas geneticamente diversas. A análise da variação genética é uma ferramenta importante para estudos epidemiológicos. Para este estudo, cepas de $S$. aureus foram selecionadas aleatoriamente por perfil molecular. Todas as cepas foram originadas do leite de vacas de mastite subclínica em fazendas do Estado do Rio de Janeiro. As cepas deS. aureus foram caracterizadas usando perfis de análise de genes de virulência, tipagem agre spa, eletroforese em gel de campo pulsado (PFGE) e tipagem de sequência de foco múltiplo (MLST). 47\% (8/17) das cepas testadas foram positivas para o gene icaA; $82.3 \%$ (14/17) para o gene icaD; $41 \%$ (7/17) para o gene fbnA; $47 \%$ (8/17) positivo para

\section{B] $\mathrm{M}$ \\ Brazilian Journal of Veterinary Medicine}

p-ISSN 0100-2430

e-ISSN 2527-2179

○

How to cite: Soares, B. S., Motta, C. C., Barbieri, N. L., Melo, D. A., Gomez, M. A., Alencar, T. A., Coelho, I. S., Coelho, S. M. O., Logue, C. M., \& Souza, M. M. S. (2021). Molecular characterization and genetic diversity of Staphylococcus aureus isolates of dairy production farms in Rio de Janeiro, Brazil. Brazilian Journal of Veterinary Medicine, 43 . e001120. https://doi.org/10.29374/2527-2179. bjvm001120

Received: September 04, 2020.

Accepted: January 20, 2021.

\title{
*Correspondence
}

Dayanne Araújo de Melo

Departamento de Microbiologia e Imunologia

Veterinária, Universidade Federal Rural do Rio de Janeiro - UFRRJ

BR-465, KM 7

CEP 23897-000, Seropedica (RJ), Brasil

E-mail: daymelo.com@gmail.com

Copyright Soares et al. This is an Open Access article distributed under the terms of the Creative Commons Attribution Non-Commercial License, which permits unrestricted non-commercial use, distribution and reproduction in any medium provided the original work is properly cited. 
ogene fbnB; 94\% (16/17) para o gene hlAe70.5\% (12/17) para o gene hlB. Esses resultados de virulência geraram 11 perfis diferentes. A maioria das cepas (58.8\% - 10/17) foi classificada como tipo II pelo sistema agr. A tipificação por spa identificou sete tipos diferentes. A análise por PFGE encontrou extensa heterogeneidade genética e nenhum clone foi observado. A análise do MLST gerou cinco tipos diferentes de ST / CC. Considerando os resultados observados no presente estudo, uma elevada variedade genética de cepas de $S$. aureus associada à presença de diferentes fatores de virulência justificou a ausência de cepas clonais nas propriedades avaliadas. Além disso, a definição de cepas clonais assim como a dinâmica populacional em S. aureus não é totalmente compreendida, pois há um número limitado de estudos em S. aureus associados à mastite bovina.

Palavras-chave: Mastite bovina, perfil de virulência, tipagem molecular.

\section{Introduction}

In Dairy cattle, various species of microorganisms are implicated in infectious mastitis, especially Staphylococcus aureus, which causes contagious mastitis that could be clinical or chronic (usually subclinical) whose infection and dissemination usually occur during milking (Bardiau et al., 2014).

Mastitis caused by S. aureus is a result of the production of several virulence factors (VFs), which may contribute in different ways to the pathogenesis of the organism. Pathogenic differences of $S$. aureus strains may be a result of the geographical distribution, host, tissue type, and number of combination of virulence genes may influence the pathogenic potential of $S$. aureus strains (Bar-Gal et al., 2015).

The ability of $S$. aureus to produce biofilm is considered as a critical virulence factor capable of influencing the pathogenesis of mastitis. Biofilm aids in the adhesion and colonization of the organism in the mammary gland epithelium. The association between biofilm in infections and drug resistance has led to a growing interest in the characterization of the genes involved in biofilm formation. A single locus has been detected in most isolates of $S$. aureus of mastitic origin, indicating its potential role as a virulence factor in the pathogenesis of mastitis in ruminants (Melchior et al., 2006).

Another VF that is associated not only with adhesion but also internalization by cells is fibronectin-binding proteins $(\mathrm{FBN}) \mathrm{A}$ and $\mathrm{B}$ that are multifunctional microbial surface components recognizing adhesive matrix molecules (MSCRAMMs) that recognize fibronectin, elastin, and fibrinogen. FBN promotes the internalization of $S$. aureus in epithelial and endothelial cells that are generally not phagocytic, favors the spread of bacteria from the bloodstream to internal organs, and the evasion of the immune response and the action of antibiotics (Burke et al., 2010).

VFs involved in toxins production in S. aureus play a significant role in intramammary infections pathogenicity. $\alpha$ - and $\beta$-hemolysins are pore-forming exotoxins that can induce inflammatory changes in mammalian cells, inactivating the immune system, their direct cytotoxic effect degrades tissues, providing nutrients for bacteria and facilitating their dispersion to new sites (Haveri et al., 2007).

A high number of $S$. aureus genotypes from cattle herds worldwide have been studied to develop better strategies for the treatment of mastitis (Kot et al., 2016). Regulatory circuitry that controls virulence and adaptation of $S$. aureus to the environment is complex. This regulatory system can receive signals from the external environment to modulate biofilm formation and produce various exoproducts in a manner appropriate at the infection site (Ster et al., 2005). One of the regulatory systems, agr, encodes a constituent component of quorum sensing that is activated by bacterial density through auto-induced peptide secretion. Activation of agr follows the production of the molecule RNA III, which is an effector molecule of the agr system. RNA III follows the reduction of surface proteins, such as adhesins required for colonization. At the same time, RNA III allows the production of secreted proteins, such as nucleases and proteases, both of which participate in the release of biofilm bacteria (Novick \& Geisinger, 2008; Otto et al., 2013).

Understanding the clonal relationship among strains is essential to determine the source and routes of infection, identify an outbreak, traceroute of transmission, recognize particularly virulent strains and evaluate the effectiveness of control measures (Pérez-Losada et al., 2013).

Methods commonly used to type and subtype $S$. aureus strain include Pulsed Field Gel Electrophoresis (PFGE) (Middleton et al., 2002), spa gene typing (Shopsin et al., 1999) and Multilocus Sequence Typing (MLST) (Smith et al., 2005). Although PFGE is considered a gold standard as a strain typing method for this genus and species, this method has greater discriminatory power in relation to other techniques (Adkins et al., 2016). The present study aimed to evaluate the 
genetic diversity of a collection of $S$. aureus isolated from bovine mastitis through the screening for VFs, agr and spa typing, PFGE and MLST.

\section{Material and methods}

\section{Sampling}

A total of 120 milk samples were collected from cows presenting subclinical mastitis identified by California Mastitis Tests (CMT) from October to November 2012, from seven dairy farms located in the cities of Barra do Piraí, Vassouras, Passa Três, Paraíba do Sul, Rio das Flores and Carmo in the state of Rio de Janeiro, Brazil. Fifty-three strains of S. aureus were recovered and identified by phenotypic tests (Koneman et al., 2012) and confirmed by amplification of the coa gene (Hookey et al., 1998) and nuc (Ciftci et al., 2009) as showed in Table1. Staphylococcus aureus standard strain ATCC 29213 was used as control. A total of 17 isolates of S. aureus were randomly selected for the present study, which were from four dairy farms initially selected, considering the virulence profile observed.

\section{DNA extraction}

Bacterial total DNA extraction was performed according to the protocol established by Tito et al. (2015).

\section{Virulence genes}

The analysis of VFs comprised the detection of the genes icaA and icaD (Vasudevan et al., 2003), implicated in biofilm production, fnbA and $f n b B$, that encodes fibronectin-binding proteins (El-Sayed et al., 2006) and the hemolysin genes $b / A$ and $h / B$ (Nilsson et al., 1999), that encodes $\alpha$ - and $\beta$-hemolysins were performed by PCR (Polimerase Reaction Chain) as shown at Table 1. ATCC 29213 S. aureus was used as quality control.

Table 1. List of primers used to identify Staphylococcus aureus specie and virulence factors (VFs).

\begin{tabular}{|c|c|c|}
\hline $\begin{array}{l}\text { Gene/ PCR } \\
\text { Product }\end{array}$ & Sequence (5' -3') & Program/ Reference \\
\hline $\begin{array}{l}\text { coa } \\
\text { (Variável) }\end{array}$ & $\begin{array}{l}\text { ATA GAG ATG CTG GTA CAG G } \\
\text { GCT TCC GAT TGT TCG ATG C }\end{array}$ & $\begin{array}{l}94^{\circ} \mathrm{C} 4 \mathrm{~min}\left(94^{\circ} \mathrm{C} 1 \mathrm{~min}, 60^{\circ} \mathrm{C} 1 \mathrm{~min}, 72^{\circ} \mathrm{C}\right. \\
1 \mathrm{~min}) \times 30 \text { and } 72^{\circ} \mathrm{C} 5 \mathrm{~min} \text { (Hookey et al. } \\
1998 \text { ). }\end{array}$ \\
\hline $\begin{array}{l}\text { пuс } \\
\text { (279 bp) }\end{array}$ & $\begin{array}{l}\text { GCG ATT GAT GGT GAT ACG GTT } \\
\text { AGC CAA GCC TTG ACG AAC TAA AGC }\end{array}$ & $\begin{array}{l}94^{\circ} \mathrm{C} 5 \mathrm{~min}\left(94^{\circ} \mathrm{C} 45 \mathrm{~s}, 68^{\circ} \mathrm{C} 45 \mathrm{~s},\right. \\
\left.72^{\circ} \mathrm{C} 90 \mathrm{~s}\right) \times 30 \text { and } 72^{\circ} \mathrm{C} 10 \mathrm{~min} \\
\text { (Ciftci et al., 2009). }\end{array}$ \\
\hline pan-agr & ATG CAC ATG GTG CAC ATG C & $\begin{array}{l}\left(94^{\circ} \mathrm{C} 1 \mathrm{~min}, 55^{\circ} \mathrm{C} 1 \mathrm{~min}, 72^{\circ} \mathrm{C} 1 \mathrm{~min}\right) \text { x } 25 \\
\text { (Shopsin et al., } 2003) \text {. }\end{array}$ \\
\hline$i c a \mathrm{~A}$ & CCT AAC TAA CGA AAG GTA G & \multirow{2}{*}{$\begin{array}{l}\left(92^{\circ} \mathrm{C} 45 \mathrm{~s}, 49^{\circ} \mathrm{C} 45 \mathrm{~s}, 72^{\circ} \mathrm{C} 1 \mathrm{~min}\right) \times 30 \text { and } \\
72^{\circ} \mathrm{C} 7 \mathrm{~min} \text { (Vasudevan et al., (2003). }\end{array}$} \\
\hline (1315bp) & AAG ATA TAG CGA TAA GTG C & \\
\hline$i c a \mathrm{D}$ & AAA CGT AAG AGA GGT GG & \multirow{2}{*}{$\begin{array}{l}\left(92^{\circ} \mathrm{C} 45 \mathrm{~s}, 49^{\circ} \mathrm{C} 45 \mathrm{~s}, 72^{\circ} \mathrm{C} 1 \mathrm{~min}\right) \times 30 \text { and } \\
72^{\circ} \mathrm{C} 7 \mathrm{~min} \text { (Vasudevan et al., 2003). }\end{array}$} \\
\hline (381bp) & GGC AAT ATG ATC AAG ATA C & \\
\hline$f b n A$ & GCG GAG ATC AAA GAC AA & \multirow{2}{*}{$\begin{array}{l}\left(94^{\circ} \mathrm{C} 30 \mathrm{~s}, 60^{\circ} \mathrm{C} 30 \mathrm{~s}, 72^{\circ} \mathrm{C} 1 \mathrm{~min}\right) \text { x } 30 \\
\text { (El-Sayed et al., 2006). }\end{array}$} \\
\hline (1279 bp) & CCA TCT ATA GCT GTG TGG & \\
\hline$f b n B$ & GGA GAA GGA ATT AAG GCG & \multirow{2}{*}{$\begin{array}{l}\left(94^{\circ} \mathrm{C} 30 \mathrm{~s}, 50^{\circ} \mathrm{C} 30 \mathrm{~s}, 72^{\circ} \mathrm{C} 1 \mathrm{~min}\right) \text { x } 30 \\
\text { (El-Sayed et al., 2006). }\end{array}$} \\
\hline (812 bp) & GCC GTC GCC TTG AGC GT & \\
\hline hlA & CTG ATT ACT ATC CAA GAA ATT CGA TTG & \multirow{2}{*}{$\begin{array}{l}94^{\circ} \mathrm{C} 5 \mathrm{~min},\left(94^{\circ} \mathrm{C} 1 \mathrm{~min}, 50^{\circ} \mathrm{C} 1 \mathrm{~min} ., 72^{\circ} \mathrm{C}\right. \\
1 \mathrm{~min}) \times 30 \text { and } 72^{\circ} \mathrm{C} 7 \mathrm{~min} \text { (Nilsson et al., } \\
1999 \text { ). }\end{array}$} \\
\hline (210 bp) & CTT TCC AGC CTA CTT TTT TAT CAG T & \\
\hline$h l B$ & GTG CAC TTA CTG ACA ATA GTG C & \multirow{2}{*}{$\begin{array}{l}94^{\circ} \mathrm{C} 5 \mathrm{~min},\left(94^{\circ} \mathrm{C} 1 \mathrm{~min}, 50^{\circ} \mathrm{C} 1 \mathrm{~min} ., 72^{\circ} \mathrm{C}\right. \\
1 \mathrm{~min}) \times 30 \text { and } 72^{\circ} \mathrm{C} 7 \mathrm{~min} \text { (Nilsson et al., } \\
\text { 1999). }\end{array}$} \\
\hline (300 bp) & GTT GAT GAG TAG CTA CCT TCA GT & \\
\hline
\end{tabular}




\section{Molecular typing}

agr system

Classification of agr system groups was based on the hyper variable domain of agr locus according to Shopsin et al. (2003), as showed at Table 2. A sensu primer, pan-agr, corresponding to conserved sequences of the $a g r \mathrm{~B}$ gene, was used in all reactions, combined with four anti-sensu primers, each one specific for the amplification of a single agr group based on the agr locus polymorphism.

\section{spa typing}

spa typing was performed according to Shopsin et al. (1999), as showed at table 2, and ATCC 29213 S. aureus was used as quality control. PCR products were purified using Exo-SAP-IT ${ }^{\oplus}$ (USB Corporation, Cleveland, Ohio) as recommended by the manufacturer and then sequenced. The sequences generated were edited using the Bioedit program (Hall, 1999) and Mega version 7.0 (Kumar et al., 2016), and later were analyzed using the DNAGear program (Faroq et al., 2012) for spa type designation.

\section{Pulsed Field Gel Electrophoresis (PFGE)}

PFGE typing was performed according to protocol established by the CDC (Centers for Disease Control and Prevention, 2013). Salmonella Braenderup H9812 was used as standard control. Gel images were imported into BioNumerics (Applied Maths ${ }^{\circledR}$ ) for analysis. Macrorestriction patterns were compared using the BioNumerics Fingerprinting software (Version 6.5, Applied Math, Austin, TX). The similarity index of the isolates was calculated using the Dice correlation coefficient option of the software with a position tolerance of $1 \%$ and an optimization of 0.5\%. The unweighted-pair group method using average linkages (UPGMA) was used to construct a dendrogram.

\section{Multilocus sequence Typing- MLST}

MLST typing was performed according to protocol described by Enright et al. (2000), considering the amplification of housekeeping genes ( $\operatorname{arc\mathrm {C}}, \operatorname{aro\mathrm {E}}, g l p \mathrm{~F}, g m k$, pta, tpi e $y q i \mathrm{~L}$ ), as showed at Table 2. ATCC 29213 S. aureus was used as quality control. PCR products were purified using ExoSAP-IT (USB Corporation, Cleveland, Ohio) as recommended by the manufacturer and then sequenced. Sequences were edited using the program BioEdit (Hall, 1999) and Mega version 7.0 (Aanensen \& Spratt, 2005) and the allele and sequence types (STs) were determined using the MLST website (Trust Pharmacy, 2020).

Table 2. List of primers used to typing Staphylococcus aureus.

\begin{tabular}{|c|c|c|c|}
\hline Gene & Sequence $\left(5^{\prime}-3^{\prime}\right)$ & Program & Reference \\
\hline pan-agr & ATG CAC ATG GTG CAC ATG C & $\begin{array}{c}\left(94^{\circ} \mathrm{C} 1 \mathrm{~min}, 55^{\circ} \mathrm{C}\right. \\
\left.1 \mathrm{~min}, 72^{\circ} \mathrm{C} 1 \mathrm{~min}\right) \times 25\end{array}$ & $\begin{array}{l}\text { Shopsin et al. } \\
\text { (2003) }\end{array}$ \\
\hline $\operatorname{agr} I$ & GTC ACA AGT ACT ATA AGC TGC GAT & $\begin{array}{c}\left(94^{\circ} \mathrm{C} 1 \mathrm{~min}, 55^{\circ} \mathrm{C}\right. \\
\left.1 \mathrm{~min}, 72^{\circ} \mathrm{C} 1 \mathrm{~min}\right) \mathrm{x} 25\end{array}$ & $\begin{array}{l}\text { Shopsin et al. } \\
\text { (2003) }\end{array}$ \\
\hline agrII & GTA TTA CTA ATT GAA AAG TGC CAT AGC & $\begin{array}{c}\left(94^{\circ} \mathrm{C} 1 \mathrm{~min}, 55^{\circ} \mathrm{C}\right. \\
\left.1 \mathrm{~min}, 72^{\circ} \mathrm{C} 1 \mathrm{~min}\right) \times 25\end{array}$ & $\begin{array}{c}\text { Shopsin et al. } \\
\text { (2003) }\end{array}$ \\
\hline agrIII & CTG TTG AAA AAG TCA ACT AAA AGC TC & $\begin{array}{c}\left(94^{\circ} \mathrm{C} 1 \mathrm{~min}, 55^{\circ} \mathrm{C}\right. \\
\left.1 \mathrm{~min}, 72^{\circ} \mathrm{C} 1 \mathrm{~min}\right) \times 25\end{array}$ & $\begin{array}{l}\text { Shopsin et al. } \\
\text { (2003) }\end{array}$ \\
\hline
\end{tabular}




\begin{tabular}{|c|c|c|c|}
\hline agrIV & CGA TAA TGC CGTA ATA CCC G & $\begin{array}{c}\left(94^{\circ} \mathrm{C} 1 \mathrm{~min}, 55^{\circ} \mathrm{C}\right. \\
\left.1 \mathrm{~min}, 72^{\circ} \mathrm{C} 1 \mathrm{~min}\right) \times 25\end{array}$ & $\begin{array}{l}\text { Shopsin et al. } \\
\text { (2003) }\end{array}$ \\
\hline \multirow[t]{2}{*}{$\operatorname{arc}$} & TTG ATT CAC CAG CGC GTA TTG TC & $\begin{array}{l}95^{\circ} \mathrm{C} 5 \mathrm{~min}\left(95^{\circ} \mathrm{C}\right. \\
1 \mathrm{~min}, 58^{\circ} \mathrm{C} 1 \mathrm{~min}, \\
\left.72^{\circ} \mathrm{C} 1 \mathrm{~min}\right) 30 \mathrm{X}\end{array}$ & \multirow[t]{2}{*}{$\begin{array}{l}\text { Enright et al. } \\
\quad(2000)\end{array}$} \\
\hline & AGG TAT CTG CTT CAA TCA GCG & $72^{\circ} \mathrm{C} 5 \mathrm{~min}$ & \\
\hline \multirow[t]{2}{*}{ aro } & ATC GGA AAT CCT ATT TCA CAT TC & $\begin{array}{l}95^{\circ} \mathrm{C} 5 \mathrm{~min}\left(95^{\circ} \mathrm{C}\right. \\
1 \mathrm{~min}, 58^{\circ} \mathrm{C} 1 \mathrm{~min}, \\
\left.72^{\circ} \mathrm{C} 1 \mathrm{~min}\right) 30 \mathrm{X}\end{array}$ & \multirow[t]{2}{*}{$\begin{array}{l}\text { Enright et al. } \\
\text { (2000) }\end{array}$} \\
\hline & GGT GTT GTA TTA ATA ACG ATA TC & $72^{\circ} \mathrm{C} 5 \mathrm{~min}$ & \\
\hline \multirow[t]{2}{*}{$g l p$} & CTA GGA ACT GCA ATC TTA ATC C & $\begin{array}{l}95^{\circ} \mathrm{C} 5 \mathrm{~min}\left(95^{\circ} \mathrm{C}\right. \\
1 \mathrm{~min}, 58^{\circ} \mathrm{C} 1 \mathrm{~min}, \\
\left.72^{\circ} \mathrm{C} 1 \mathrm{~min}\right) 30 \mathrm{X}\end{array}$ & \multirow[t]{2}{*}{$\begin{array}{l}\text { Enright et al. } \\
\quad(2000)\end{array}$} \\
\hline & TGG TAA AAT CGC ATG TCC AAT TC & $72^{\circ} \mathrm{C} 5 \mathrm{~min}$ & \\
\hline \multirow[t]{2}{*}{$g m k$} & ATC GTT TTA TCG GGA CCA TC & $\begin{array}{l}95^{\circ} \mathrm{C} 5 \mathrm{~min}\left(95^{\circ} \mathrm{C}\right. \\
1 \mathrm{~min}, 58^{\circ} \mathrm{C} 1 \mathrm{~min}, \\
\left.72^{\circ} \mathrm{C} 1 \mathrm{~min}\right) 30 \mathrm{X}\end{array}$ & \multirow[t]{2}{*}{$\begin{array}{l}\text { Enright et al. } \\
\qquad(2000)\end{array}$} \\
\hline & TCA TTA ACT ACA ACG TAA TCG TA & $72^{\circ} \mathrm{C} 5 \mathrm{~min}$ & \\
\hline \multirow[t]{2}{*}{ pta } & GTT AAA ATC GTA TTA CCT GAA GG & $\begin{array}{l}95^{\circ} \mathrm{C} 5 \mathrm{~min}\left(95^{\circ} \mathrm{C}\right. \\
1 \mathrm{~min}, 58^{\circ} \mathrm{C} 1 \mathrm{~min} \\
\left.72^{\circ} \mathrm{C} 1 \mathrm{~min}\right) 30 \mathrm{X}\end{array}$ & \multirow[t]{2}{*}{$\begin{array}{l}\text { Enright et al. } \\
\qquad(2000)\end{array}$} \\
\hline & GAC CCT TTT GTT GAA AAG CTT AA & $72^{\circ} \mathrm{C} 5 \mathrm{~min}$ & \\
\hline \multirow[t]{2}{*}{ Tip } & TCG TTC ATT CTG AAC GTC GTG AA & $\begin{array}{l}95^{\circ} \mathrm{C} 5 \mathrm{~min}\left(95^{\circ} \mathrm{C}\right. \\
1 \mathrm{~min}, 58^{\circ} \mathrm{C} 1 \mathrm{~min}, \\
\left.72^{\circ} \mathrm{C} 1 \mathrm{~min}\right) 30 \mathrm{X}\end{array}$ & \multirow[t]{2}{*}{$\begin{array}{l}\text { Enright et al. } \\
\text { (2000) }\end{array}$} \\
\hline & TTT GCA CCT TCT AAC AAT TGT AC & $72^{\circ} \mathrm{C} 5 \mathrm{~min}$ & \\
\hline \multirow[t]{2}{*}{$y q i$} & CAG CAT ACA GGA CAC CTA TTG GC & $\begin{array}{l}95^{\circ} \mathrm{C} 5 \mathrm{~min}\left(95^{\circ} \mathrm{C}\right. \\
1 \mathrm{~min}, 58^{\circ} \mathrm{C} 1 \mathrm{~min}, \\
\left.72^{\circ} \mathrm{C} 1 \mathrm{~min}\right) 30 \mathrm{X}\end{array}$ & \multirow[t]{2}{*}{$\begin{array}{l}\text { Enright et al. } \\
\text { (2000) }\end{array}$} \\
\hline & CGT TGA GGA ATC GAT ACT GGA AC & $72^{\circ} \mathrm{C} 5 \mathrm{~min}$ & \\
\hline \multirow[t]{2}{*}{ spa } & AGA CGA TCC TTC GGT GAG C & $\begin{array}{c}95^{\circ} \mathrm{C} 10 \mathrm{~min}\left(95^{\circ} \mathrm{C}\right. \\
30 \mathrm{~s}, 60^{\circ} \mathrm{C} 30 \mathrm{~s}, 72^{\circ} \\
45 \mathrm{~s}) 30 \mathrm{X}\end{array}$ & \multirow[t]{2}{*}{$\begin{array}{l}\text { Shopsin et al. } \\
\text { (1999) }\end{array}$} \\
\hline & GCT TTT GCA ATG TCA TTT ACT G & $72010 \mathrm{~min}$. & \\
\hline
\end{tabular}

\section{Results}

\section{Detection of VF"s}

The characteristics of $S$. aureus isolates in this study are shown in Table 3. The analyses of VFs demonstrated the presence of majority of the genes evaluated. The distribution of VFs generated 11 virulence profiles, and the most prevalent were profile $6(i c a \mathrm{~A}+/ i c a \mathrm{D}+/ f b n \mathrm{~A}+/ f n b \mathrm{~B}-/ h l \mathrm{~A}+$ and $h / \mathrm{B}^{+}$) presenting 17.6\% (3/17) of the isolates followed by profile 1 (positive for all virulence genes), profile $3(i c a \mathrm{~A}+/ i c a \mathrm{D}+/ f b n \mathrm{~A}-/ f n b \mathrm{~B}+/ h l \mathrm{~A}+$ and $h l \mathrm{~B}+)$, profile $4(i c a \mathrm{~A}-/ i c a \mathrm{D}+/ f b n \mathrm{~A}-/ f n b \mathrm{~B}+/ h l \mathrm{~A}+$ and $h / \mathrm{B}+$ ) and profile 11 (icaA-/icaD-/fbnA-/fnbB-/hlA + and $h / \mathrm{B}+$ ) which were observed in $11.7 \%(2 / 17)$ of the isolates (Table 3).

Considering the presence of VFs was also possible to observe that most of the strains tested presented the genes icaA and/or icaD (profiles 1, 2, 3, 4, 5, 6, 7, 8 and 9) (Table 3), responsible to biofilm production, presenting $82.3 \%$ (14/17) of the isolates the icaD gene and $47 \%$ (8/17) of the isolates the icaA gene. 
Considering the presence of fibronectin-binding proteins genes ( $f b n \mathrm{~A}$ and $f b n \mathrm{~B}$ ) the majority of the isolates presenting one or both of them (profiles 1, 2, 3, 4, 5, 6 and 7) as showed at Table 3. In this study, $41 \%(7 / 17)$ of the strains were positive for $f b n A$ gene and $47 \%(8 / 17)$ were positive for $f b n B$ gene.

The detection of the genes responsible for the production of hemolysins $\alpha$ and $\beta$, $b l A$ and $b / B$ respectively, demonstrated that only one profile (profile 5) did not present this capacity, as showed at Table 3. 94\% (16/17) of the strains were positive for the $h l A$ gene and 70.5\% $(12 / 17)$ were positive for the $h l B$ gene.

\section{Molecular typing of $S$. aureus}

The agr typing classified the $S$. aureus isolates predominantly as agr type-II, 58.8\% (10/17). It should be noted that $41.2 \%$ (7/17) of the strains were classified as non-typeable.

The spa typing detected seven different spa-types (t605, t359, t23, t693, t432, t17, t10) among the 17 strains tested. spa-type 605 was the most prevalent, 59.2\% (9/17), being found in isolates recovered from three different farms (Table 3 ).

Through PFGE technique it was possible to observe high genetic heterogeneity among the strains examined (Figure 1). All patterns were relatively unique to the strains examined. Strains 208 and 225 appear to be closely related as they differ in only one fragment. In addition, both strains share similar virulence profiles (Table 3) and were recovered from the same farm (farm C).

Table 3. Characterization of Staphylococcus aureus isolates and virulence and typing analyses.

\begin{tabular}{|c|c|c|c|c|c|c|c|c|c|c|c|c|c|c|}
\hline \multirow[b]{2}{*}{ Strain } & \multirow[b]{2}{*}{ Cow } & \multirow[b]{2}{*}{ Farm } & \multirow[b]{2}{*}{ City } & \multicolumn{7}{|c|}{ Virulence analyses } & \multicolumn{4}{|c|}{ Typing analyses } \\
\hline & & & & icaA & $i c a \mathrm{D}$ & $f b n \mathrm{~A}$ & $f b n \mathrm{~B}$ & blA & $h / \mathrm{B}$ & $\begin{array}{c}\text { Virulence } \\
\text { profile }\end{array}$ & $a g r$ & spa & PFGE & MLST \\
\hline 47 & 363 & A & $\begin{array}{l}\text { Barra do } \\
\text { Pirai }\end{array}$ & - & - & - & - & + & + & 11 & NT & t693 & XVII & CC97 \\
\hline 54 & 369 & $\mathrm{~A}$ & $\begin{array}{l}\text { Barra do } \\
\text { Pirai }\end{array}$ & - & - & - & - & + & + & 11 & NT & t605 & VIII & ST3087 \\
\hline 76 & 614 & $\mathrm{~A}$ & $\begin{array}{l}\text { Barra do } \\
\text { Pirai }\end{array}$ & - & - & - & - & + & - & 10 & NT & t359 & XV & ST126 \\
\hline 360 & Serena & B & $\begin{array}{l}\text { Passa } \\
\text { Três }\end{array}$ & + & + & + & - & + & + & 6 & 2 & $\mathrm{t} 432$ & $\mathrm{X}$ & ST97 \\
\hline 208 & $\begin{array}{l}1110 \\
(39933)\end{array}$ & $\mathrm{C}$ & Carmo & + & + & + & + & + & + & 1 & 2 & t605 & VI & ST126 \\
\hline 225 & 57 & $\mathrm{C}$ & Carmo & + & + & + & - & + & + & 6 & 2 & t605 & VII & CC126 \\
\hline 241 & 551 & $\mathrm{C}$ & Carmo & + & + & + & - & + & + & 6 & 2 & t605 & IX & ST126 \\
\hline 262 & 518 & $\mathrm{C}$ & Carmo & - & + & - & + & + & + & 4 & 2 & t605 & $I$ & CC126 \\
\hline 281 & 219 & C & Carmo & - & + & - & + & + & + & 4 & NT & $\mathrm{t} 23$ & IV & ST747 \\
\hline 295 & $\begin{array}{l}858 \\
(30976)\end{array}$ & $\mathrm{C}$ & Carmo & - & + & - & - & + & - & 8 & NT & $\mathrm{t} 17$ & XIII & ST5 \\
\hline 300 & 391 & $\mathrm{C}$ & Carmo & - & + & - & + & - & - & 5 & NT & $\mathrm{t} 10$ & III & ST5 \\
\hline 310 & 872 & C & Carmo & + & + & + & + & + & + & 1 & 2 & t359 & XVI & ST126 \\
\hline 311 & 683 & $\mathrm{C}$ & Carmo & + & + & - & + & + & + & 3 & NT & $\mathrm{t} 23$ & II & ST126 \\
\hline 325 & Abeia & C & Carmo & - & + & + & - & + & - & 7 & 2 & t605 & XI & ST126 \\
\hline 336 & Pintura & $\mathrm{D}$ & Vassouras & - & + & + & + & + & - & 2 & 2 & t605 & XIV & ST126 \\
\hline 338 & Germana & $\mathrm{D}$ & Vassouras & + & + & - & + & + & + & 3 & 2 & t605 & XII & ST126 \\
\hline 339 & Germana & D & Vassouras & + & + & - & - & + & + & 9 & 2 & t605 & $\mathrm{V}$ & ST126 \\
\hline
\end{tabular}

NT: nontypeable; (+): number of isolates that amplified; (-): number of isolates that not amplified. 


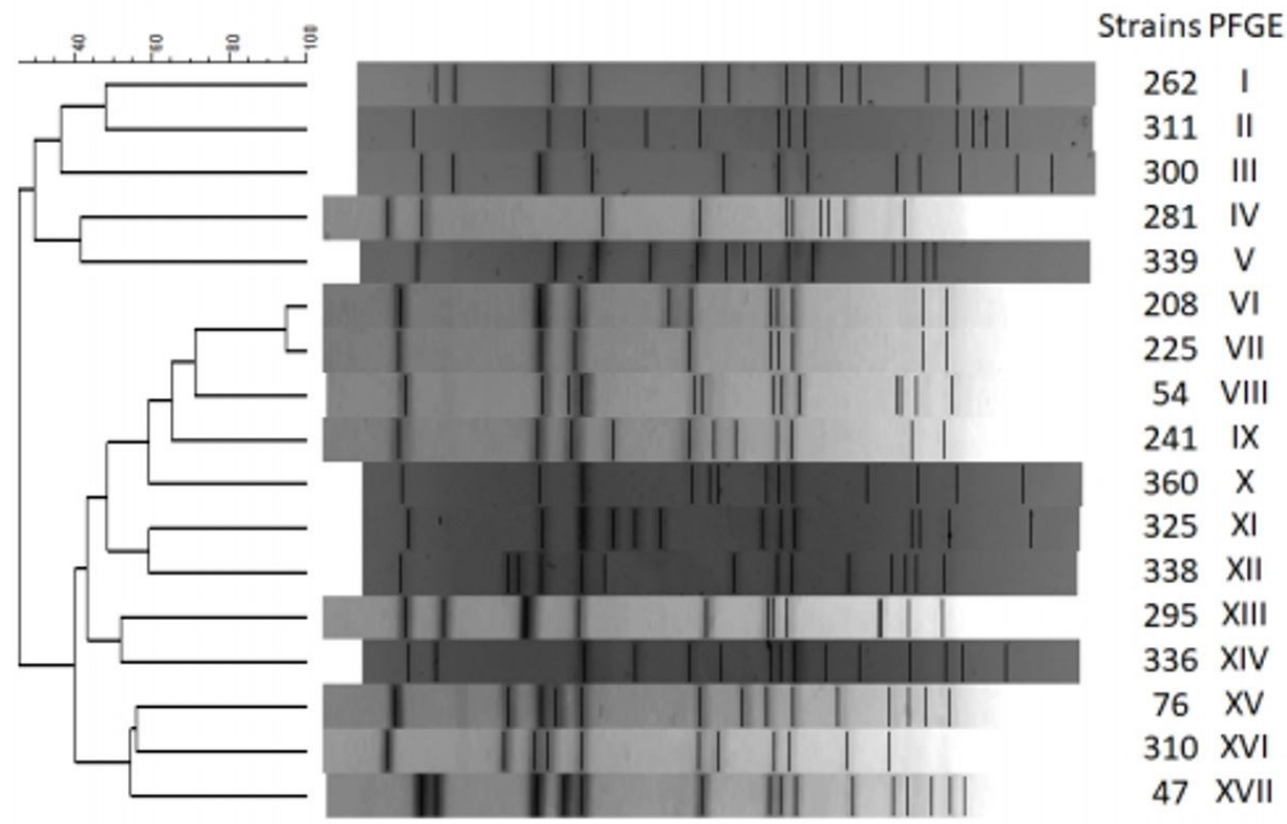

Figure 1. Similarity dendogram generated from data obtained from Staphylococcus aureus typing using PFGE technique (Pulsed Field Gel Electrophoresis) using the Dice grouping method, BioNumerics.

They also share ST 126 and spa type - spa 605 and were both classified as agr type-II but were isolated from different animals.

Analyses of MLST typing demonstrated five different ST/CC types (ST/CC126, ST5, ST/CC97, ST3087 and ST747) (Table 3). Most of the strains, 64.7\% (11/17), were identified as belonging to ST/CC 126 and this was distributed on three different farm properties.

\section{Discussion}

\section{Analyses of VFs detection of $S$. aureus}

Most $S$. aureus strains have the genetic capacity to produce biofilm. Our results corroborate with Marques et al. (2017) that showed a high abundance of genes icaA and icaD in S. aureus isolates, producing biofilm in samples from bovine intramammary infections in Brazil.

Acosta et al. (2018) reported a high frequency of $f n b \mathrm{~A}(94 \%), f n b \mathrm{~B}(81.3 \%), b l \mathrm{~A}(88 \%)$ and $h l \mathrm{~B}$ (88.3\%) genes in S. aureus from milk samples, and these genes were more abundant in samples from bovine milk than goat milk in a recent study developed in cow and goat herds raised in three different geographical regions of the state of Pernambuco, Brazil, and these results corroborate with our data.

The importance of monitoring biofilm production (icaA and icaD), fibronectin-binding proteins (FBN) A and B ( $f n b \mathrm{~A}$ and $f n b \mathrm{~B}$ ) and $\alpha$ - and $\beta$-hemolysins ( $h / \mathrm{A}$ and $h / \mathrm{B}$ ) genes in $S$. aureus isolated from dairy environment is reinforced due to its high frequency amongst the isolates investigated (Table 3). It supports the idea that these VFs are strictly related to severe mastitis cases.

\section{Analyses of molecular typing of $S$. aureus}

Agr typing of S. aureus isolates showed a predominance of agr type-II and non-typeable. Similar results were reported by Fabres-Klein et al. (2015) who also detected the prevalence of agr type-II suggesting that this type is better adapted to the dairy environment, and by Marques et al. (2017) that also noted that not all S. aureus strains examined could be classified, when analyzing S. aureus from bovine mastitis in Brazil.

spa type 605 has been reported in several studies of bovine mastitis (Guinane et al., 2010; Sakwinska et al. 2011). This spa type has also been reported as an ordinary strain associated 
with bovine mastitis in the state of Rio de Janeiro and also appears to be linked with ST126 (Aires-de-Sousa et al., 2007; Rabello et al., 2007).

Considering PFGE analyses, the similarity between the strains 208 and 225 could be occurred by a small-scale mutation or by the presence of mobile genetic elements. The fact that they shared several characteristics and only differed at the animal origin suggests that there may be similar strains circulating and causing mastitis in this particular herd. Previous studies conducted by our research group on distinct farms of the present study showed similar results, high genetic heterogeneity, and the absence of clonally related strains (Marques et al., 2013). Rabello et al. (2007) also reported similar results when using the same technique to evaluate $S$. aureus strains from Rio de Janeiro state. A possible explanation for the high genetic heterogeneity of $S$. aureus strains in properties in the state of Rio de Janeiro can be explained by the fact that the production is carried out on small properties with distinct characteristics for milking and breed. This high heterogeneity would also imply the difficulty of obtaining effective prophylactic measures to control mastitis because of the diversity of strains implicated.

ST 126 has been reported in several studies associated with bovine mastitis outbreaks (Guinane et al., 2010; Sakwinska et al., 2011) and has also been reported as implicated in bovine mastitis in the state of Rio de Janeiro (Aires-de-Sousa et al., 2007; Rabello et al., 2007). A study by Smyth et al. (2009) showed that ST126 is usually associated with agr type-II and spa type t605. A similar result was observed in our study that presenting a prevalence of spa type t605. However, some strains were also identified as t359 and t23, suggesting that spa type and ST are not exclusively linked. This can be explained by using a single locus method such as spa typing for macroepidemiologic investigations, which can distort the underlying clonal relationships (Nübel et al., 2008).

ST 97 has also been detected in previous studies of bovine mastitis in the state of Rio de Janeiro, this ST appears to be widely distributed in several countries around the world, in addition to being related to LA-MRSA strains and has also been implicated as a causative agent of bovine mastitis (Meemken et al., 2010; Smith et al., 2005).

\section{Comparative analysis of the genetic profiles generated by different molecular typing techniques}

The clustering of strains, according to the virulence genes distribution, yielded 11 distinct profiles. Most strains shared the same virulence profile but not the same type through other typing and subtyping techniques, as already reported by Melles et al. (2004) in a study evaluating the population dynamics and expansion of pathogenic clones of $S$. aureus in healthy humans. Their study suggested that not all clones of $S$. aureus share the same VFs because the strains may be under different environmental pressure that results in strains from some clonal lineages being more virulent than others.

Regarding spa-type analysis of the strains examined in this study, seven different spa types were detected among the 17 strains examined. Genotypic characterization based on the investigation of a locus of the highly variable tandem repeat region of the spa gene is another successful tool for the genotypic characterization of $S$. aureus. spa gene typing also considers the recombination of X region events. Since recombination occurs more frequently within this region, this typing method typically provides more types (spa) than MLST. Although spa typing and MLST are usually concordant and allow a similar classification for distinct genotypes, there are also several cases of sorting errors by the spa typing technique, which are most likely caused by recombination events. Thus, spa typing is a useful method to obtain information about the genotype of the strains but should not replace the MLST technique (Strommenger et al., 2008).

Regarding the detection of STs by MLST technique, five different sequence types (ST) or clonal complexes (CC) were detected. According to MLST technique, a clone is defined based on the sequence type, so an isolate is defined as a clone if it shares the same ST. This definition of clones using the MLST technique is very useful for investigating the evolutionary history of bacteria. However, it may lead to misconception since the term clone is defined as bacterial isolates with indistinguishable genotypes. However, in the case of bacteria, it is not possible to define clones based only on this definition, since high rates of mutation and recombination, as well as the acquisition or loss of mobile genetic elements, can lead (depending on the species) to a bacterial genome that is highly variable. Permanent diversification of the ancestral genome results in an increasingly diverse set of genotypes. The MLST method, however, 
provides an efficient method to identify genetic lineages that share the same ancestor, due to MLST method being based on the amplification of multiple internal fragments in the DNA sequence of relatively conserved housekeeping genes (with approximately 450-500 bp for each gene) that are present in all strains of the same species. Genetic relationships between the strains is determined by the analysis of these housekeeping genes sequences, which are compared by analysis of nucleotide substitution in the sequence. Based on this definition, clones (MLST) include isolates of the same sequence type but are not necessarily genetically identical (Ranjbar et al., 2014; Spratt, 2004).

PFGE analysis generated quite distinct profiles demonstrating the heterogeneity of the strains studied. Compared with MLST results, this technique allows detection of more frequent genomic alterations. Thus, using PFGE it is possible to demonstrate the diversity of $S$. aureus strains sharing the same sequence type and thus show that clones based on MLST definition are not necessarily genetically identical (Murchan et al., 2003).

PFGE and MLST techniques are considered as some of the best methods for molecular typing of $S$. aureus but did not have a reasonable correlation when applied individually. However, when combined, it is possible to obtain an accurate overview of the population of $S$. aureus present in dairy herds. In view of the results generated from this study, it can be concluded that the choice of the typing method and its application depends on the type of epidemiological study that is to be carried out. However, it should be emphasized that in order to carry out the study, the application of multiple typing techniques that can be combined provides higher power to the analysis and the research question.

Although there is much still that remains to be investigated and understand regarding recombination events in $S$. aureus it seems clear that it occurs frequently enough to be detectable but not often enough to destroy vertical or clonal signals. Understanding how the mix of horizontal and vertical processes of clonal evolution contributes to the structuring and evolution of this bacterial species is a goal to be achieved, and techniques such as Whole Genome Sequencing (WGS) can clarify these aspects.

However, for these studies to be reliably validated, epidemiological and clinical biases need to be eliminated. Currently, most of the phylogenomic studies of S. aureus consist of sample collection and analysis related to clonal complexes of medical interest, which hinders an evolutionary view of these transformations (Planet et al., 2016). Regarding isolates from animal production, especially those of bovine origin, these studies are still emerging and point to a highly diversified phylogenetic structure. Possibly, due to the intense selection pressure exerted by the use of antimicrobials and sanitizing agents in the production environment. Also, the great diversity of bacterial species in a constant competition that induces elaboration of strategies for survival and adaptation to the host, fomites, and the environment as a whole.

\section{Conclusions}

A high genetic variety of $S$. aureus strains associated of the presence of different virulence factors justified the absence of clonal strains at the properties evaluated. Besides that, the definition of $S$. aureus clonal strains is not fully understood since there are a limited number of studies in S. aureus associated with bovine mastitis. Therefore, for a better understanding of phylogenetic diversity of this agent more studies are necessary to clarify the role of population dynamics and clones of S. aureus at the pathogenicity of mastitis in bovines, improving the monitoring and the control of this disease.

\section{Acknowledgements}

The National Council for Scientific and Technological Development (CNPq, Rio de Janeiro, Brazil - process 308528/2011-5), Foundation for Research Support in the State of Rio de Janeiro (FAPERJ; process E-26/112.658/2012) and Coordination for the Improvement of Higher Education Personnel (CAPES- process 99999.010413/2014-06) supported this study.

\section{Ethics statement}

The study followed all criteria established by Ethical Research Committee at UFRRJ for research involved non-human vertebrate (CEUA NO 3664040915). 


\section{Financial support}

BSS, TAA - Received a scholarship from CAPES (Coordenação de Aperfeiçoamento de Pessoal de Nivel Superior), CCM, DAM, MAG - Receive a scholarship from CNPq (Conselho Nacional de Desenvolvimento Científico e Tecnológico).

\section{Conflict of interests}

BSS, CCM, NLB, DAM, MAG, TAA, SMOC, ISC, CML and MMSS- No conflict of interests.

\section{Authors' contributions}

BSS, CCM, NLB, DAM, MAG, TAA, SMOC, ISC, CML and MMSS - All authors made substantial contributions to the conception, design, acquisition, analysis, or interpretation of data for this work. BSS, CCM, DAM, MAG, TAA- visited the milk farms, collected, and processed all samples. BSS, NLB, CML, worked at the typification of S. aureus isolates using PFGE technique.

\section{Availability of complementary results}

All information obtained as a result of the study is included in the manuscript.

The study was carried out at Laboratório de Bacteriologia Veterinária, Departamento de Microbiologia e Imunologia Veterinária, Universidade Federal Rural do Rio de Janeiro - UFRRJ, Seropedica, RJ, Brasil, and Bacterial Pathogenesis Laboratory, Department of Veterinary Microbiology and Preventive Medicine, Iowa State University, Iowa, USA.

\section{References}

Aanensen, D. M., \& Spratt, B. G. (2005). The multilocus sequence typing network: mlst. net. Nucleic Acids Research, 33(suppl_2), 728-733.

Acosta, A. C., Oliveira, P. R. F., Albuquerque, L., Silva, I. F., Medeiros, E. S., Costa, M. M., Pinheiro Junior, J. W., \& Mota, R. A. (2018). Frequency of Staphylococcus aureus virulence genes in milk of cows and goats with mastitis. Pesquisa Veterinária Brasileira, 38(11), 2029-2036. http://dx.doi.org/10.1590/1678-5150-pvb-5786.

Adkins, P. R. F., Middleton, J. R., \& Fox, L. K. (2016). Comparison of Virulence Gene Identification, Ribosomal Spacer PCR, and Pulsed-Field Gel Electrophoresis for Typing of Staphylococcus aureus Strains Isolated from Cases of Subclinical Bovine Mastitis in the United States. Journal of Clinical Microbiology, 54(7), 1871-1876. http://dx.doi.org/10.1128/JCM.03282-15. PMid:27194685.

Aires-de-Sousa, M., Parente, C. E., Vieira-da-Motta, O., Bonna, I. C., Silva, D. A., \& De Lencastre, H. (2007). Characterization of Staphylococcus aureus isolates from buffalo, bovine, ovine, and caprine milk samples collected in Rio de Janeiro State, Brazil. Applied and Environmental Microbiology, 73(12), 3845-3849. http://dx.doi.org/10.1128/AEM.00019-07. PMid:17449696.

Bardiau, M., Detilleux, J., Farnir, F., Mainil, J. G., \& Ote, I. (2014). Associations between properties linked with persistence in a collection of Staphylococcus aureus isolates from bovine mastitis. Veterinary Microbiology 169(1-2), 74-79. http://dx.doi.org/10.1016/j.vetmic.2013.12.010. PMid:24444863.

Bar-Gal, G. K., Blum, S. E., Hadas, L., Ehricht, R., Monecke, S., \& Leitner, G. (2015). Host-specificity of Staphylococcus aureus causing intramammary infections in dairy animals assessed by genotyping and virulence genes. Veterinary Microbiology, 176(1), 143-154. http://dx.doi.org/10.1016/j.vetmic.2015.01.007. PMid:25631254.

Burke, F. M., Mccormack, N., Rindi, S., Speziale, P., \& Foster, T. J. (2010). Fibronectin-binding protein B variation in Staphylococcus aureus. BMC Microbiology, 10(160), 1-15. http://dx.doi.org/10.1186/1471-2180-10-160. PMid:20515471.

Centers for Disease Control and Prevention - CDC. (2013). Oxacillin-resistant Staphylococcus aureus on PulseNet (OPN): Laboratory Protocol for Molecular Typing of S. aureus by Pulsed field gel electrophoresis (PFGE) growing cultures: plug preparation. National Molecular Subtyping Netw foodborne. Disease Surveillance, $\cdots \cdot \bullet, 1-24$.

Ciftci, A., Findik, A., Onuk, E. E., \& Savasan, S. (2009). Detection of methicillin resistance and slime factor production of Staphylococcus aureus in bovine mastitis. Brazilian Journal of Microbiology, 40(2), 254-261. http://dx.doi.org/10.1590/S1517-83822009000200009. PMid:24031354.

El-Sayed, A., Alber, J., Lammer, C., Jager, S., Wolter, W., \& Vázquez, H. C. (2006). Comparative study on genotypic properties of Staphylococcus aureus isolated from clinical and subclinical mastitis in Mexico. Veterinaria (México), 37(2), 165-179.

Enright, M. C., Day, N. P., Davies, C. E., Peacock, S. J., \& Spratt, B. G. (2000). Multilocus sequence typing for characterization of methicillin-resistant and methicillin-susceptible clones of Staphylococcus aureus. Journal of Clinical Microbiology, 38(3), 1008-1015. http://dx.doi.org/10.1128/JCM.38.3.1008-1015.2000. PMid:10698988. 
Fabres-Klein, M. H., Caizer Santos, M. J., Contelli Klein, R., Nunes de Souza, G., \& de Oliveira Barros Ribon, A. (2015). An association between milk and slime increases biofilm production by bovine Staphylococcus aureus. BMC Veterinary Research, 11, 3. http://dx.doi.org/10.1186/s12917-015-0319-7. PMid:25591667.

Faroq, A. T., Brunel, A. S., Bouzinb, N., Corne, P., Bañuls, A. L., \& Shahbazkia, H. R. (2012). DNAGear-a free software for spa type identification in Staphylococcus aureus. BMC Research Notes, 5(1), 642. http://dx.doi.org/10.1186/1756-0500-5-642.

Guinane, C. M., Ben Zakour, N. L., Tormo-Mas, M. A., Weinert, L. A., Lowder, B. V., Cartwright, R. A., Smyth, D. S., Smyth, C. J., Lindsay, J. A., Gould, K. A., Witney, A., Hinds, J., Bollback, J. P., Rambaut, A., Penadés, J. R., \& Fitzgerald, J. R. (2010). Evolutionary genomics of Staphylococcus aureus reveals insights into the origin and molecular basis of ruminant host adaptation. Genome Biology and Evolution, 2(1), 454-466. http://dx.doi. org/10.1093/gbe/evq031. PMid:20624747.

Hall, T. A. (1999). BioEdit: a user-friendly biological sequence alignment editor and analysis program for Windows 95/98/NT. Nucleic Acids Symposium Series, 41(1), 95-98.

Haveri, M., Roslöf, A., Rantala, L., \& Pyörälä, S. (2007). Virulence genes of bovine Staphylococcus aureus from persistent and nonpersistent intramammary infections with different clinical characteristics. Journal of Applied Microbiology, 103(4), 993-1000. http://dx.doi.org/10.1111/j.1365-2672.2007.03356.x. PMid:17897203.

Hookey, J. V., Richardson, J. F., \& Cookson, B. D. (1998). Molecular typing of Staphylococcus aureus based on PCR restriction fragment length polymorphism and DNA sequence analysis of the coagulase gene. Journal of Clinical Microbiology, 36(4), 1083-1089. http://dx.doi.org/10.1128/JCM.36.4.1083-1089.1998. PMid:9542942.

Koneman, E. W., Allen, S. D., Janda, W. M., Schreckenberger, P. C., \& Winn, J. R. (2012). Diagnóstico microbiológico (6. ed.). Editora MEDS.

Kot, B., Szweda, P., Frankowska-Maciejewska, A., Piechota, M., \& Wolska, K. (2016). Virulence gene profiles in Staphylococcus aureus isolated from cows with subclinical mastitis in eastern Poland. The Journal of Dairy Research, 83(2), 228-235. http://dx.doi.org/10.1017/S002202991600008X. PMid:27032339.

Kumar, S., Stecher, G., \& Tamura, K. (2016). MEGA7: Molecular Evolutionary Genetics Analysis version 7.0 for bigger datasets. Molecular Biology and Evolution, 33(7), 1870-1874. http://dx.doi.org/10.1093/molbev/msw054. PMid:27004904.

Marques, V. F., Motta, C. C., Soares, B. D., Melo, D. A., Coelho, S. M., Coelho, I. D., Barbosa, H. S., \& Souza, M. M. (2017). Biofilm production and beta-lactamic resistance in Brazilian Staphylococcus aureus isolates from bovine mastitis. Brazilian Journal of Microbiology, 48(1), 118-124. http://dx.doi.org/10.1016/j.bjm.2016.10.001. PMid:27913076.

Marques, V. F., Souza, M. M. S., Mendonça, E. C. L., Alencar, T. A., Pribul, B. R., Coelho, S. M. O., Lasagno, M., \& Reinoso, E. B. (2013). Análise fenotípica e genotípica da virulência em Staphylococcus spp. e de sua dispersão clonal como contribuição ao estudo da mastite bovina em regiões do Estado do Rio de Janeiro. Pesquisa Veterinária Brasileira, 33(2), 161-170. http://dx.doi.org/10.1590/S0100-736X2013000200005.

Meemken, D., Blaha, T., Tegeler, R., Tenhagen, B. A., Guerra, B., Hammerl, J. A., Hertwig, S., Käsbohrer, A., Appel, B., \& Fetsch, A. (2010). Livestock Associated Methicillin-Resistant Staphylococcus aureus (LaMRSA) Isolated from Lesions of Pigs at Necropsy in Northwest Germany Between 2004 and 2007. Zoonoses and Public Health, 57(7-8), e143-e148. http://dx.doi.org/10.1111/j.1863-2378.2009.01313.x. PMid:20042059.

Melchior, M. B., Fink-Gremmels, J., \& Gaastra, W. (2006). Comparative assessment of the antimicrobial susceptibility of Staphylococcus aureus isolates from bovine mastitis in biofilm versus planktonic culture. Journal of Veterinary Medicine. B, Infectious Diseases and Veterinary Public Health, 53(7), 326-332. http://dx.doi. org/10.1111/i.1439-0450.2006.00962.x. PMid:16930277.

Melles, D. C., Gorkink, R. F. J., Boelens, H. A. M., Snijders, S. V., Peeters, J. K., Moorhouse, M. J., Van Der Spek, P. J., Van Leeuwen, W. B., Simons, G., Verbrugh, H. A., \& Van Belkum, A. (2004). Natural population dynamics and expansion of pathogenic clones of Staphylococcus aureus. The Journal of Clinical Investigation, 114(12), 1732-1740. http://dx.doi.org/10.1172/JCI200423083. PMid:15599398.

Middleton, J. R., Fox, L. K., Gay, J. M., Tyler, J. W., \& Besser, T. E. (2002). Use of pulsed-field gel electrophoresis for detecting differences in Staphylococcus aureus strain populations between dairy herds with different cattle importation practices. Epidemiology and Infection, 129(2), 387-395. http://dx.doi.org/10.1017/S095026880200746X. PMid:12403115.

Murchan, S., Kaufmann, M. E., Deplano, A., de Ryck, R., Struelens, M., Zinn, C. E., Fussing, V., Salmenlinna, S., Vuopio-Varkila, J., El Solh, N., Cuny, C., Witte, W., Tassios, P. T., Legakis, N., van Leeuwen, W., van Belkum, A., Vindel, A., Laconcha, I., Garaizar, J., Haeggman, S., Olsson-Liljequist, B., Ransjo, U., Coombes, G., \& Cookson, B. (2003). Harmonization of pulsed-field gel electrophoresis protocols for epidemiological typing of strains of methicillin-resistant Staphylococcus aureus: A single approach developed by consensus in 10 European laboratories and its application for tracing the spread of related strains. Journal of Clinical Microbiology, 41(4), 1574-1585. http://dx.doi.org/10.1128/JCM.41.4.1574-1585.2003. PMid:12682148. 
Nilsson, I. M., Hartford, O., Foster, T., \& Tarkowski, A. (1999). Alpha-toxin and gamma-toxin jointly promote Staphylococcus aureus virulence in murine septic arthritis. Infection and Immunity, 67(3), 1045-1049. http://dx.doi.org/10.1128/IAl.67.3.1045-1049.1999. PMid:10024541.

Novick, R. P., \& Geisinger, E. (2008). Quorum sensing in staphylococci. Annual Review of Genetics, 42(1), 541-564. http://dx.doi.org/10.1146/annurev.genet.42.110807.091640. PMid:18713030.

Nübel, U., Roumagnac, P., Feldkamp, M., Song, J. H., Ko, K. S., Huang, Y. C., Coombs, G., Ip, M., Westh, H., Skov, R., Struelens, M. J., Goering, R. V., Strommenger, B., Weller, A., Witte, W., \& Achtman, M. (2008). Frequent emergence and limited geographic dispersal of methicillin-resistant Staphylococcus aureus. Proceedings of the National Academy of Sciences of the United States of America,105(37), 14130-14135. http://dx.doi.org/10.1073/ pnas.0804178105. PMid:18772392.

Otto, M. P., Martin, E., Badiou, C., Lebrun, S., Bes, M., Vandenesch, F., Etienne, J., Lina, G., \& Dumitrescu, O. (2013). Effects of subinhibitory concentrations of antibiotics on virulence factor expression by community-acquired methicillin-resistant Staphylococcus aureus. The Journal of Antimicrobial Chemotherapy, 68(7), 1524-1532. http://dx.doi.org/10.1093/jac/dkt073. PMid:23508621.

Pérez-Losada, M., Cabezas, P., Castro-Nallar, E., \& Crandall, K. A. (2013). Pathogen typing in the genomics era: MLST and the future of molecular epidemiology. Infection, Genetics and Evolution, 16(1), 38-53. http://dx.doi. org/10.1016/j.meegid.2013.01.009. PMid:23357583.

Planet, P. J., Narechania, A., Chen, L., Mathema, B., Boundy, S., Archer, G., \& Kreiswirth, B. (2016). Architecture of a species: phylogenomics of Staphylococcus aureus. Trends in Microbiology, 25(2), 153-166. http://dx.doi. org/10.1016/j.tim.2016.09.009. PMid:27751626.

Rabello, R. F., Moreira, B. M., Lopes, R. M., Teixeira, L. M., Riley, L. W., \& Castro, A. C. (2007). Multilocus sequence typing of Staphylococcus aureus isolates recovered from cows with mastitis in Brazilian dairy herds. Journal of Medical Microbiology, 56(Pt 11), 1505-1511. http://dx.doi.org/10.1099/jmm.0.47357-0. PMid:17965353.

Ranjbar, R., Karami, A., Farshad, S., Giammanco, G. M., \& Mammina, C. (2014). Typing methods used in the molecular epidemiology of microbial pathogens: A how-to guide. The New Microbiologica, 1(37), 1-15. PMid:24531166.

Sakwinska, O., Giddey, M., Moreillon, M., Morisset, D., Waldvogel, A., \& Moreillon, P. (2011). Staphylococcus aureus host range and human-bovine host shift. Applied and Environmental Microbiology, 77(17), 5908-5915. http://dx.doi.org/10.1128/AEM.00238-11. PMid:21742927.

Shopsin, B., Gomez, M., Montgomery, S. O., Smith, D. H., Waddington, M., Dodge, D. E., Bost, D. A., Riehman, M., Naidich, S., \& Kreiswirth, B. N. (1999). Evaluation of protein A gene polymorphic region DNA sequencing for typing of Staphylococcus aureus strains. Journal of Clinical Microbiology, 37(11), 3556-3563. http://dx.doi. org/10.1128/JCM.37.11.3556-3563.1999. PMid:10523551.

Shopsin, B., Mathema, B., Alcabes, P., Said-Salim, B., Lina, G., Matsuka, A., Martinez, J., \& Kreiswirth, B. N. (2003). Prevalence of agr Specificity Groups among Staphylococcus aureus strains colonizing children and their guardians. Journal of Clinical Microbiology, 41(1), 456-459. http://dx.doi.org/10.1128/JCM.41.1.456-459.2003. PMid:12517893.

Smith, E. M., Green, L. E., Medley, G. F., Bird, H. E., Fox, L. K., Schukken, Y. H., Kruze, J. V., Bradley, A. J., Zadoks, R. N., \& Dowson, C. G. (2005). Multilocus sequence typing of intercontinental bovine Staphylococcus aureus isolates. Journal of Clinical Microbiology, 43(9), 4737-4743. http://dx.doi.org/10.1128/JCM.43.9.4737-4743.2005. PMid:16145135.

Smyth, D. S., Feil, E. J., Meaney, W. J., Hartigan, P. J., Tollersrud, T., Fitzgerald, J. R., Enright, M. C., \& Smyth, C. J. (2009). Molecular genetic typing reveals further insights into the diversity of animal-associated Staphylococcus aureus. Journal of Medical Microbiology, 58(Pt 10), 1343-1353. http://dx.doi.org/10.1099/jmm.0.009837-0. PMid:19528163.

Spratt, B. G. (2004). Exploring the concept of clonality in bacteria. Methods in Molecular Biology (Clifton, N.J.), 266(1), 323-352. http://dx.doi.org/10.1385/1-59259-763-7:323. PMid:15148426.

Ster, C., Gilbert, F. B., Cochard, T., \& Poutrel, B. (2005). Transcriptional profiles of regulatory and virulence factors of Staphylococcus aureus of bovine origin: Oxygen impact and strain-to-strain variations. Molecular and Cellular Probes, 19(4), 227-235. http://dx.doi.org/10.1016/j.mcp.2005.01.002. PMid:16038790.

Strommenger, B., Braulke, C., Heuck, D., Schmidt, C., Pasemann, B., Nübel, U., \& Witte, W. (2008). spa typing of Staphylococcus aureus as a frontline tool in epidemiological typing. Journal of Clinical Microbiology, 46(2), 574-581. http://dx.doi.org/10.1128/JCM.01599-07. PMid:18032612.

Tito, T. M., Rodrigues, N. M. B., Coelho, S. M. O., Souza, M. M. S., Zonta, E., \& Coelho, I. S. (2015). Choice of DNA extraction protocols from Gram negative and positive bacteria and directly from the soil. African Journal of Microbiological Research, 12(9), 863-871. http://dx.doi.org/10.5897/AJMR2014.7259.

Vasudevan, P., Nair, M. K., Annamalai, T., \& Venkitanarayanan, K. S. (2003). Phenotypic and genotipic characterization of bovine mastitis isolates os Staphylococcus aureus for biofilm formation. Veterinary Microbiology, 92(1-2), 179-185. http://dx.doi.org/10.1016/S0378-1135(02)00360-7. PMid:12488081. 